\title{
A PSYCHROMETRIC ANALYSIS OF THERMAL COMFORT IN LOW-RISE OFFICE BUILDINGS IN GHANA
}

\author{
C. Koranteng, D. Nyame - Tawiah and E. Quansah \\ Department of Architecture, \\ Kwame Nkrumah University of Science and Technology, \\ Kumasi, Ghana
}

\begin{abstract}
A research project on the thermal performance of office buildings in Ghana was conducted and in the process, data loggers were used to record indoor environmental conditions over a period of 12 months in five office buildings. The temperature and relative humidity values recorded were analysed and plotted on psychrometric charts. The results of the study in 15 offices were placed in psychrometric charts which showed uncomfortable indoor environmental conditions. The reasons were high relative humidity values, although the temperatures in most of the cases were below $29^{\circ} \mathrm{C}$. The impression gained during the observation period was that occupants had adapted to high humidity levels and therefore found maximum humidity levels of $80 \%$ comfortable, provided temperature values did not exceed $29^{\circ} \mathrm{C}$. This significant clue calls for further study and the adjustment of the comfort scale for the climatic context of Kumasi, Ghana.
\end{abstract}

Keywords: Psychrometric, Environment, Occupants, Comfort, Thermal

\section{INTRODUCTION}

Apart from the provision of space for diverse activities, the main task of designers is to ensure that occupants are comfortable and satisfied with the indoor environment. Moreover, designers usually provide building systems which must be operated by the occupants in order to attain comfort.

However, thermal comfort is a complex condition that determines the well-being of occupants, since numerous factors must be considered. Among the factors are the behaviour of occupants and their interaction with the environmental control systems. For instance, Nicol (2001) and, Nicol and Roaf (2005) observed that the operation of windows is a function of prevailing outdoor temperature. Rijal et al. (2008) concluded from studies of office buildings that beyond $28.1^{\circ} \mathrm{C}$, the frequency of opening windows increases. Herkel et al. (2005) and Mahdavi et al. (2007) concluded in their studies of office buildings that the operation of shades was a function of solar radiation on building facades. Furthermore, they noted that shades on the northern sides of buildings were operated less frequently than on the southern sides. Sutter et al. (2006) found out that shades were normally fully raised or lowered. Building occupants interact with available building systems in an attempt to attain thermal comfort. 


\section{$77 \quad$ Koranteng et al.}

A summary of definitions was compiled by Heerwagen (2004) stating that, "Givoni (1976) defined thermal comfort as the absence of irritation and discomfort due to heat or cold, or in a positive sense, as a state involving pleasantness. Alternatively, Fanger (1973) states that thermal comfort is the condition of mind which expresses satisfaction with the thermal environment. Fanger further notes that, because of biological variance, establishing a condition that will satisfy everyone is not likely to be achievable. Rather, the designer or the builder should instead seek to create a condition that will satisfy the largest number in a group of probable occupants."

The main factor of thermal comfort is the body's capability of balancing its own temperature with the thermal environment. This thermal balance depends on the internal heat load and energy flow (thermal exchange) of the body, which is executed through the processes of conduction, convection, radiation and evaporation (perspiration and respiration) (Gut and Ackerknecht, 1993). The main conditions allowing heat to be lost are air temperature, humidity, air velocity and mean radiant temperature (Lechner, 2001). Other minor factors are age, sex, clothing, health and activity of occupants.

For tropical regions, a comfort range of 23 $29^{\circ} \mathrm{C}$ with a relative humidity of $30-70 \%$ has been suggested by Brooks, as cited by Olgyay (1963). In addition, Koenigsberger et al. (1974) have proposed $22-27^{\circ} \mathrm{C}$ with an optimum temperature of $25^{\circ} \mathrm{C}$. Keneally (2002) is of the opinion that the general consensus of suitable design set point for tropical buildings is $25^{\circ} \mathrm{C}$ and $60 \%$ relative humidity. Ferstl (2005) suggests $22-26^{\circ} \mathrm{C}$ and $30-80 \%$ relative humidity as optimal values for indoor comfort. The American Society of Heating, Refrigeration and Air-conditioning Engineering (ASHRAE), recommends $23^{\circ} \mathrm{C}$ to $26^{\circ} \mathrm{C}$ as temperature range for summer comfort (Stein and Reynolds, 2000).

According to Hyde (2000), the neutral temperature (adaptive model) is the temperature at which a person should be neither too hot nor too cold. The comfort zone is $2^{\circ} \mathrm{C}$ below and above the neutral temperature (Eqn. 1). On the other hand, Szokolay (2004) has set the comfort zone for $90 \%$ acceptability to be $2.5^{\circ} \mathrm{C}$ above and below the neutral temperature after, $\mathrm{Au}$ liciems (1981).

$\operatorname{Tn}=17.6+0.31 \times$ To.av

Where, To.av. = the mean monthly outdoor temperature $\left({ }^{\circ} \mathrm{C}\right)$

$\mathrm{Tn}=$ neutral temperature $\left({ }^{\circ} \mathrm{C}\right)$

\section{APPROACH}

Five buildings (see Table 1), situated in different locations in Kumasi, Capital of Ashanti Region of Ghana were selected for the studies. These buildings are representative of the majority of existing low-rise office buildings and

Table 1: Overview of the selected office buildings with function, net floor area and thermal controls

\begin{tabular}{llll}
\hline Building & Function & Floor area $\left(\mathbf{m}^{2}\right)$ & Thermal controls \\
\hline CAP & University & 795 & Mixed mode \\
KCR & NGO & 1100 & Air-conditioned \\
ANG & Private & 365 & Air-conditioned \\
ROY & Construction & 1740 & Air-conditioned \\
DCD & company & 280 & Naturally ventilated \\
\hline
\end{tabular}

Journal of Science and Technology @ KNUST April 2011 
house different functions (university offices, private companies, municipal offices, etc.). The applied cooling systems typically involve split air-conditioning units. The buildings were given the codes CAP, KCR, ROY, ANG and DCD.

Data loggers were installed in 15 offices to measure indoor temperature and relative humidity levels (at 10 minutes interval) for a period of 12 months. Due to financial constraints, it was not possible to monitor outdoor weather conditions with a weather station at each building site. Therefore, five additional data loggers were used to record the outdoor temperature and relative humidity values. The recorded data was then compared with the mean maximum and minimum values received from the Kumasi weather station (see Fig. 1).

Table 2 shows the accuracy of the sensors. The measured data were analysed in spread sheets format and the various mean monthly values were plotted on psychrometric charts based upon the adaptive model (Table 3 ).

Table 2: Accuracy of the sensors

\begin{tabular}{lll}
\hline Sensor & Range & Error \\
\hline Air temperature & -20 to $70{ }^{\circ} \mathrm{C}$ & $\pm 0.4{ }^{\circ} \mathrm{C}$ \\
Relative humidity & 5 to $95 \%$ & $\pm 3 \%$ \\
\hline
\end{tabular}

The adaptive model based on the work of Auliciems (1981) and recommendation by Szokolay (2004) for $90 \%$ acceptability was used to derive the comfort zone for Kumasi (Table 3 and Fig. 2). The generated mean maximum, minimum and hourly values during the working hours were then plotted on psychrometric charts.

\section{RESULTS AND DISCUSSION}

The recorded indoor air temperature and relative humidity values (mean monthly hourly maximums, minimums and hourly means, during the working hours) have been plotted on psychrometric charts to analyse the thermal conditions pertaining in the office spaces (buildings CAP, KCR, ANG, ROY and DCD) in relation to the comfort zone.

In Fig. 2, a shift of the comfort zone to the lower (left) and to the higher (right) temperatures is demonstrated with the mean hourly temperature and relative humidity values in Kumasi for representative days in the months of February and August. The shift of the comfort zone is minimal because of the minor difference in the outdoor temperature (Tn difference of $0.9^{\circ} \mathrm{C}$, Table 3) during the warmest month (February) and the coolest month (August).

During the warmest period (dry season), mean temperature levels are high, and in some cases exceeding $30^{\circ} \mathrm{C}$. However, the mean temperature levels hardly exceed $28^{\circ} \mathrm{C}$ during the rainy season, especially in the months of June, July and August. The relative humidity values are rather high, averagely $80 \%$ and the effect is the experience of uncomfortable sensations. This is a characteristic of warm and humid countries, where temperature and relative humidity values are high with intense solar radiation and cloudy conditions existing most of the time.

Table 3: Neutral temperature for $90 \%$ acceptability (Adaptive model)

\begin{tabular}{lllllllllllll}
\hline & Jan & Feb & Mar & Apr & May & Jun & Jul & Aug & Sep & Oct & Nov & Dec \\
\hline To.av. & 26.5 & 28.6 & 28.4 & 27.9 & 27.6 & 26.6 & 25.5 & 25.3 & 26.0 & 26.4 & 27.0 & 27.3 \\
Tn+2.5 & 28.3 & 29.0 & 28.9 & 28.8 & 28.7 & 28.3 & 28.0 & 27.9 & 28.2 & 28.3 & 28.5 & 28.6 \\
Tn & 25.8 & 26.5 & 26.4 & 26.3 & 26.2 & 25.8 & 25.5 & 25.4 & 25.7 & 25.8 & 26.0 & 26.1 \\
Tn-2.5 & 23.3 & 24.0 & 23.9 & 23.8 & 23.7 & 23.3 & 23.0 & 22.9 & 23.2 & 23.3 & 23.5 & 23.6 \\
\hline
\end{tabular}




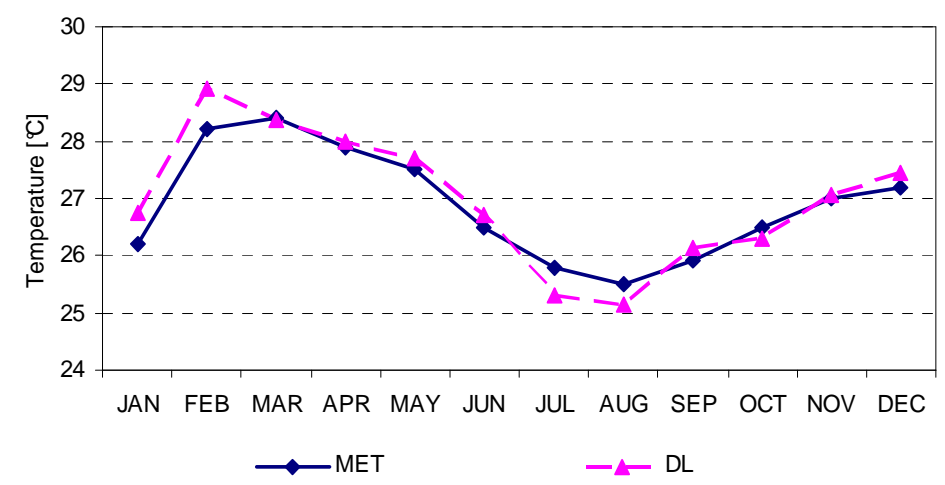

Fig.1: Comparison of mean outdoor temperature measurements at office locations (DL) with Kumasi weather station data (MET)

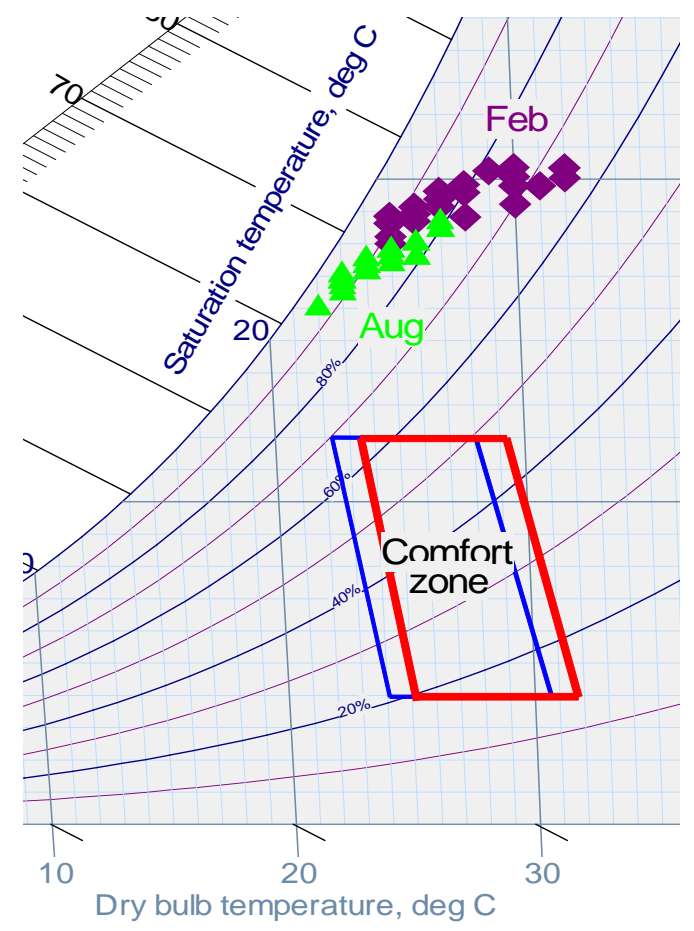

Fig.2: Mean hourly temperature and relative humidity values in Kumasi for representative days in the months of February and August

\section{CAP building}

The mean monthly hourly maximum temperature and relative humidity values of the offices in CAP, based on measurements from $8-17$ hours indicate that with the exception of the months of January and February, all months were above the comfort zone (Fig. 3).

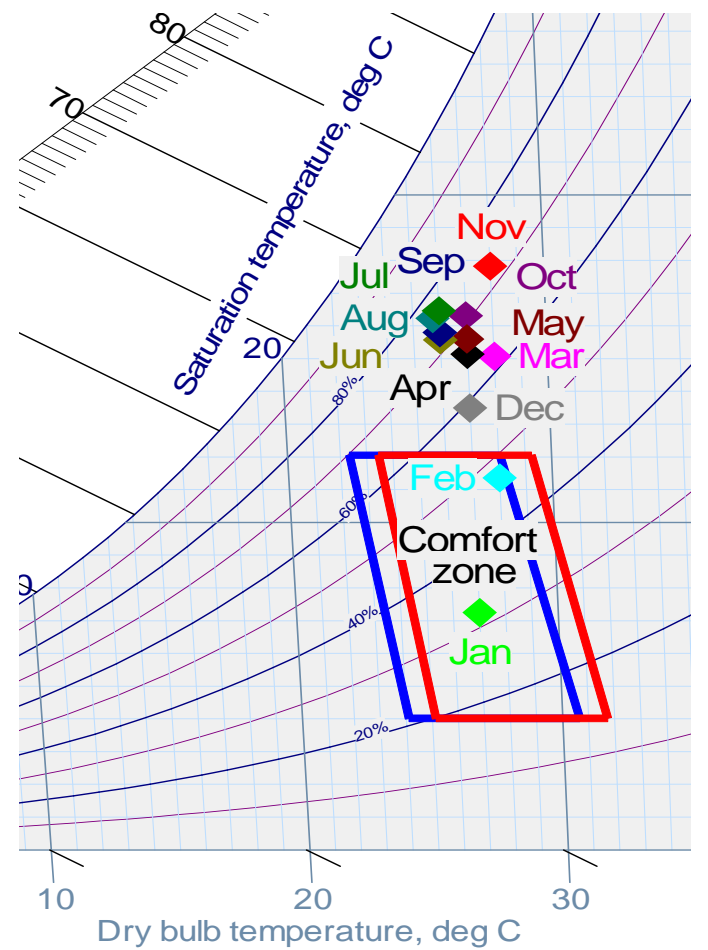

Fig.3: Mean monthly hourly maximum temperature and relative humidity values of offices in CAP (based on measured data from 8 to 17 hrs.) 
The average relative humidity decreased from the outdoor value of $80 \%$ to $70 \%$. The temperature values measured were below $28^{\circ} \mathrm{C}$, however, the higher humidity levels resulted in most of the months being outside the comfort zone.

In Fig. 4, the mean monthly hourly temperature values measured resulted in only the month of January being comfortable. The month of February is just above the comfort zone. The mean relative humidity is around the $70 \%$ mark.

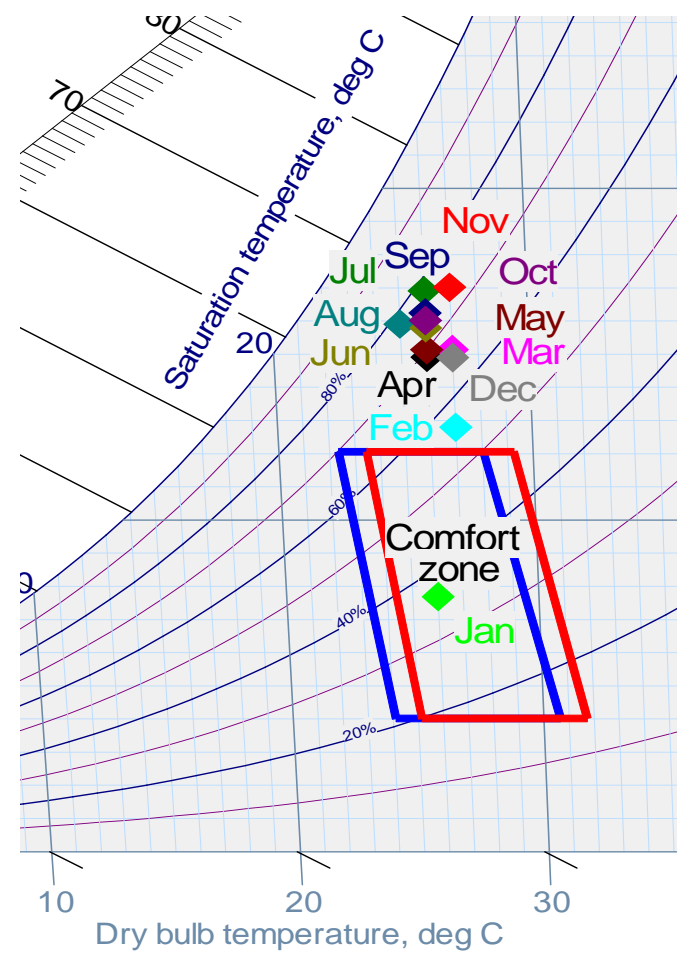

Fig.4: Mean monthly hourly temperature and relative humidity values of offices in CAP (based on measured data from 8 to 17 hrs.)

The mean monthly hourly minimum temperature and relative humidity also resulted in the month of January in the comfort zone. The mean temperature values were around the $25^{\circ} \mathrm{C}$ mark but the corresponding humidity levels were relatively high (Fig. 5).

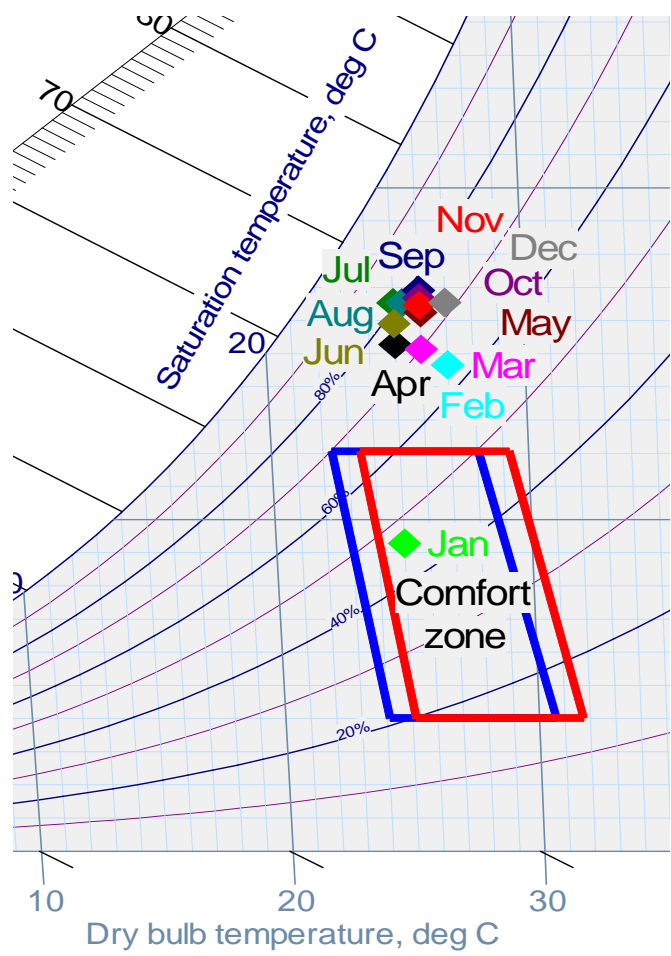

Fig.5: Mean monthly hourly minimum temperature and relative humidity values of offices in CAP (based on measured data from 8 to 17 hrs.)

The reasons for the performance of this building could be the effects of occupants regarding interaction with building systems (windows, fans, air-conditioners, etc.) (Mahdavi et al., 2007 and Rijal et al., 2008), and the efficiency of the environmental control systems (Lechner, 2001). Averagely, the temperature values were below $28^{\circ} \mathrm{C}$ and this shows that most of the occupants still considered the indoor climate to be comfortable. According to the comfort values given for tropical regions $\left(23-29^{\circ} \mathrm{C}\right.$ with a relative humidity of $30-70 \%$ ) by Brooks, as cited by Olgyay (1963), this building could be seen as comfortable. The high humidity levels might not be a serious problem due to adaptive capabilities of the building occupants (Koranteng, 2010). The evaluation of the office spaces on the measured temperatures alone would rate the building as a comfortable work- 


\section{Koranteng et al.}

ing environment. The effects of humidity on thermal comfort in the climatic context of $\mathrm{Ku}$ masi may need to be studied in detail.

\section{KCR building}

The mean monthly hourly maximum temperature and relative humidity values in KCR resulted in the months of January and February being in the comfort zone, even though the month of February is represented on the border line of the comfort zone (Fig. 6).

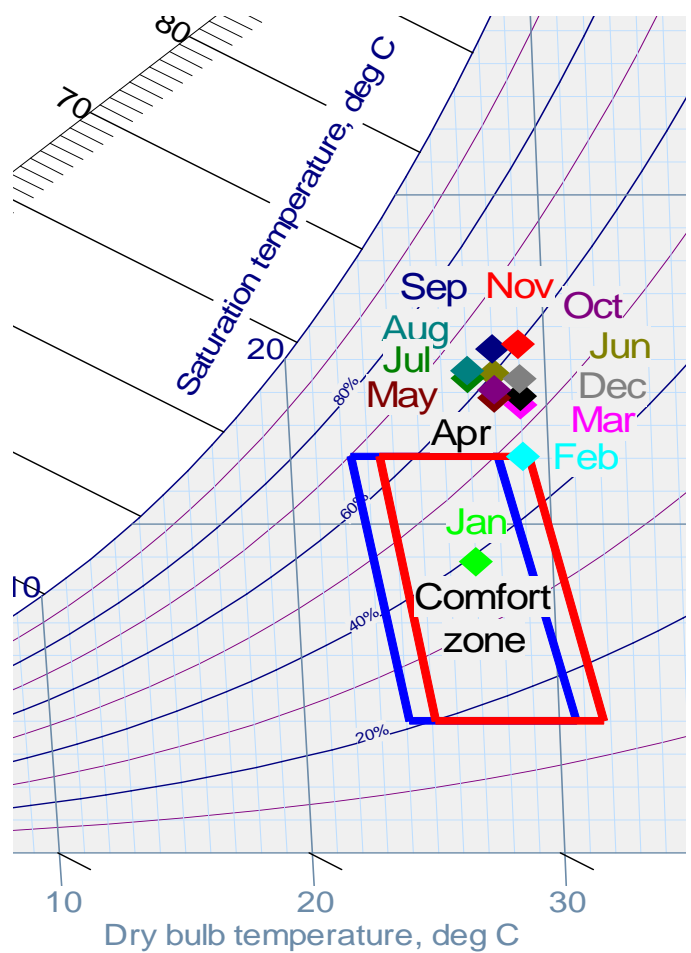

Fig.6: Mean monthly hourly maximum temperature and relative humidity values of offices in KCR (based on measured data from 8 to 17 hrs.)

The mean relative humidity values of the months outside the comfort zone decreased to about $58 \%$ when compared to the CAP building. This value is within the recommendations for comfort suggested by Brooks, as cited by Olgyay (1963) and Ferstl (2005). The recorded maximum temperature value was around $30^{\circ} \mathrm{C}$.
This is higher than the maximum value computed for $90 \%$ acceptability based on the adaptive model (Szokolay, 2004). The discrepancies could be resulting from the efficiency of the air -conditioners and the different room sizes as related to air circulation (Lechner, 2001). The louvre blade and sliding glass windows in CAP (mixed-mode) and KCR (air-conditioned) with possible effects of frequency of operation are factors which influence thermal comfort (Herkel et al., 2005, and Nicol and Roaf, 2005).

In Fig. 7, the mean monthly hourly temperature and relative humidity values are represented. Comfortable months are January and February. The maximum temperature value was around $29^{\circ} \mathrm{C}$ and the mean relative humidity level was $60 \%$.

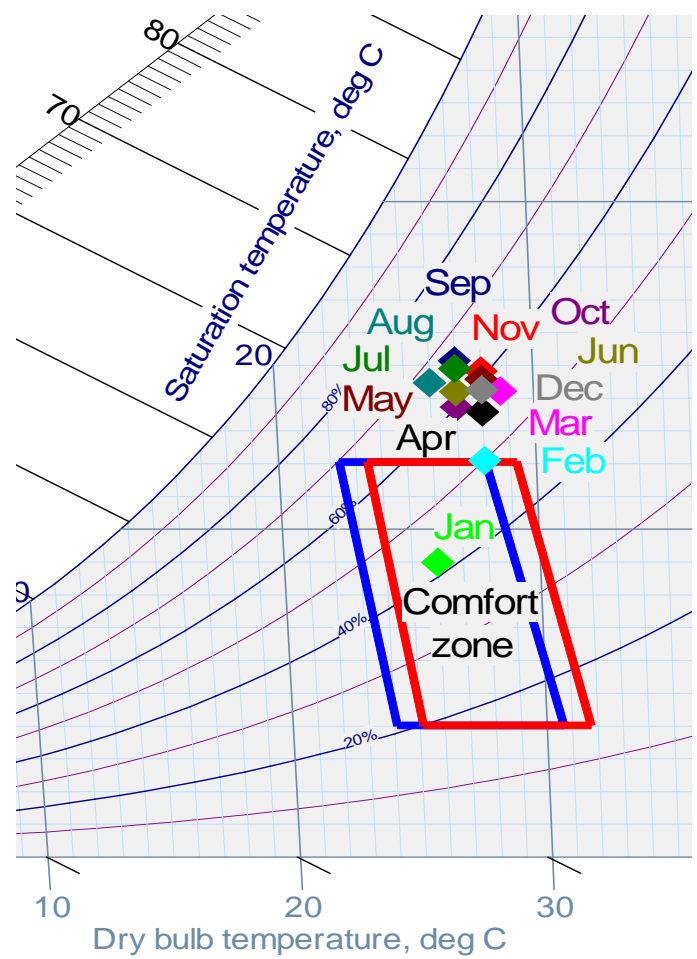

Fig.7: Mean monthly hourly temperature and relative humidity values of offices in KCR (based on measured data from 8 to 17 hrs.) 
The mean monthly hourly minimum temperature and relative humidity values resulted in the comfort zone only in January. The mean temperature values were around the $27^{\circ} \mathrm{C}$ mark with the relative humidity value at $65 \%$ (Fig. 8)

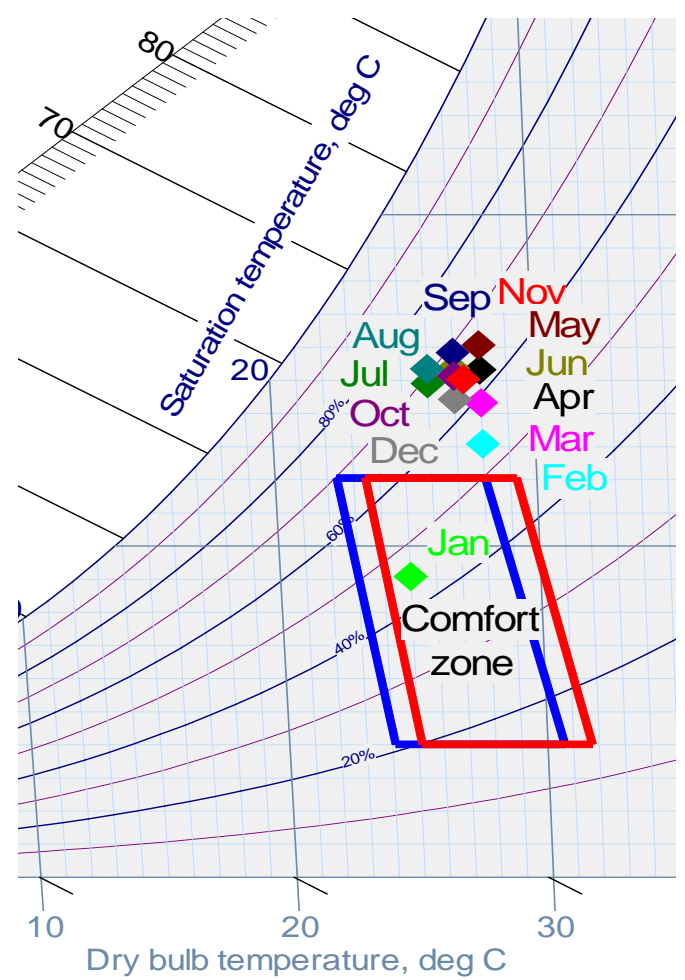

Fig.8: Mean monthly hourly minimum temperature and relative humidity values of offices in KCR (based on measured data from 8 to 17 hrs.)

The mean monthly hourly minimum values did not deviate much from the generally accepted design set point of $25^{\circ} \mathrm{C}$ and $60 \%$ relative humidity (Keneally, 2002).

The relative poor performance of this building as compared to CAP could be due to the building form and orientation (Gut and Ackerknecht, 1993). The CAP building, which is a rectangular block, had no windows on the eastern and western sides as compared to the L-shaped building of KCR. The behaviour of occupants at workspaces (Sutter et al., 2006) and building system efficiency are also factors that could lead to thermal comfort problems (Mokamelkhah, 2007). It has been found that occupants mostly tend to switch on lights upon arrival in the office and lights are switched off generally at the close of work leading to higher thermal loads during the working hours (Love, 1998 and Pigg et al., 1996).

\section{ANG building}

At ANG, the mean monthly hourly maximum temperature and relative humidity values resulted in almost all the months being in the comfort zone (Fig. 9).

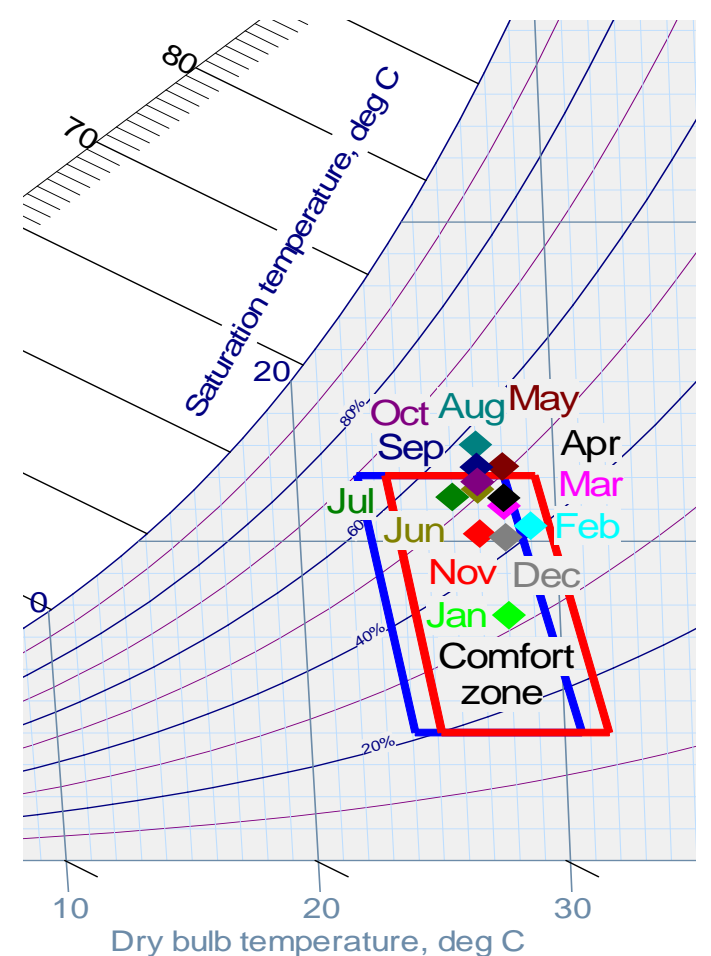

Fig.9: Mean monthly hourly maximum temperature and relative humidity values of offices in ANG (based on measured data from 8 to 17 hrs.)

The month of August was just above the comfort zone. The mean maximum temperature value was about $30^{\circ} \mathrm{C}$; however, the relatively 
lower humidity levels of around $50 \%$ had the effect of the months being in the comfort zone. The temperature value alone would not have gained acceptance by $90 \%$ of the occupants (Szokolay, 2004).

The mean monthly hourly temperature and relative humidity values resulted in five months being outside the comfort zone (Fig. 10).

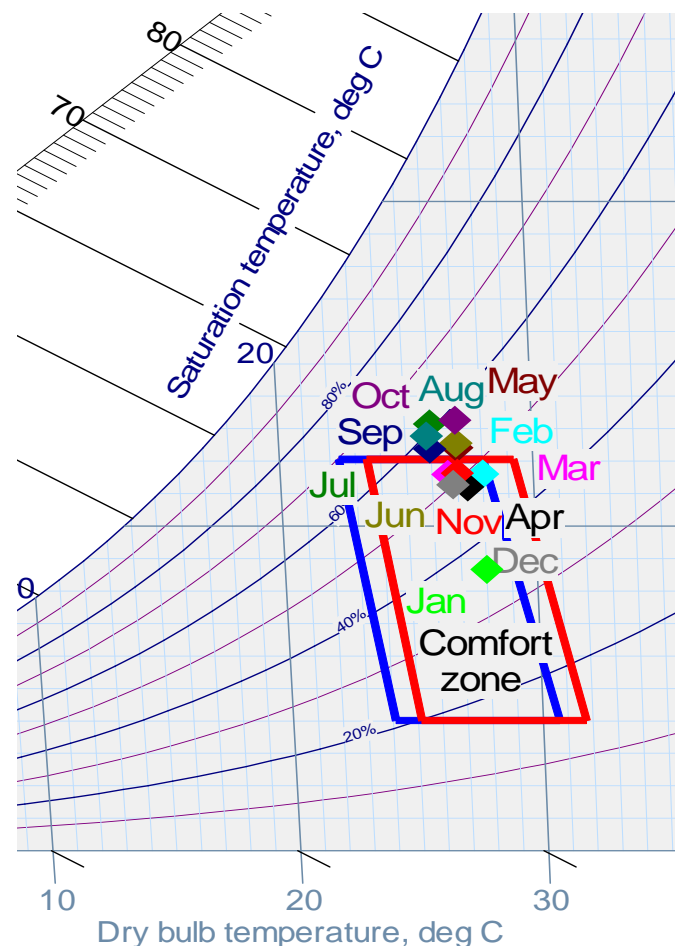

Fig.10: Mean monthly hourly temperature and relative humidity values of offices in ANG (based on measured data from 8 to 17 hrs.)

The mean temperature values were from 24 to $28^{\circ} \mathrm{C}$. An increase in the humidity levels resulted in this representation. Even though the mean monthly hourly minimum temperature values in the offices were low, averagely $25^{\circ} \mathrm{C}$, the relatively higher humidity levels caused all the months to be uncomfortable, with the exception of January (Fig. 11). This is against the temperature proposal of $22-27^{\circ} \mathrm{C}$ with an opti- mum value of $25^{\circ} \mathrm{C}$ as being comfortable, without considering the effect of relative humidity (Koenigsberger et al., 1974).

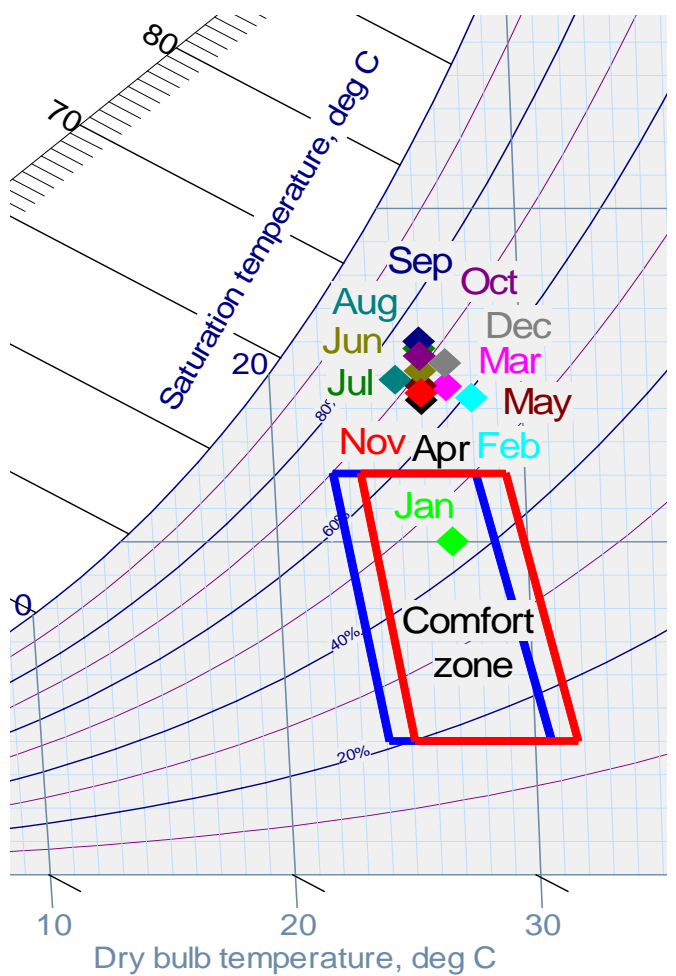

Fig.11: Mean monthly hourly minimum temperature and relative humidity values of offices in ANG (based on measured data from 8 to 17 hrs.)

Possible aspects to explain this performance are the windowless offices (65\% of the offices), orientation of the building, the relatively small sizes of the offices as compared to the other buildings, the efficiency of the air-conditioners and lastly the behaviour of the occupants in relation to thermal comfort (Lechner, 2001 and Mohammadi, 2007).

\section{ROY building}

High mean temperature values were measured in the curtain wall building of ROY; a maximum value of $30^{\circ} \mathrm{C}$ in February, March and April (Fig. 12). With the exception of January, 
the months of February, October and September were on the border of the comfort zone. Comparatively, the maximum temperature values in ROY were higher than in the buildings discussed above.

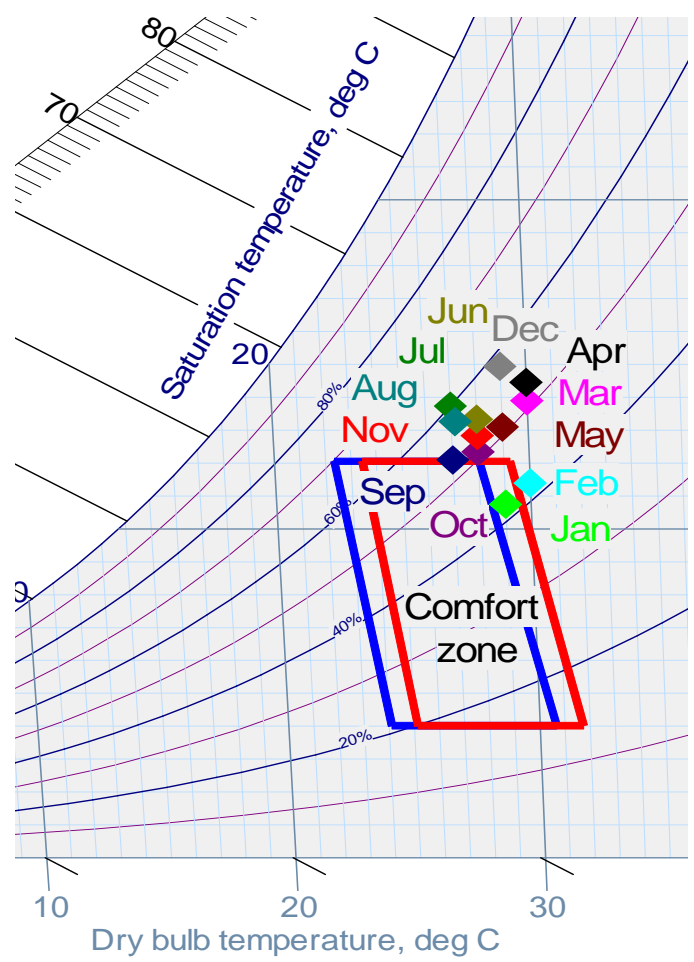

Fig.12: Mean monthly hourly maximum temperature and relative humidity values of offices in ROY (based on measured data from 8 to 17 hrs.)

The mean monthly hourly temperature and relative humidity levels resulted in the reduction of the air temperature to a mean value of $28^{\circ} \mathrm{C}$ (Fig. 13). The mean relative humidity value was about $58 \%$.

The hourly minimum temperature and relative humidity values (Fig. 14) were similar to those in the other buildings. The humidity levels were high resulting in all the months being outside the comfort zone (January on the border line).

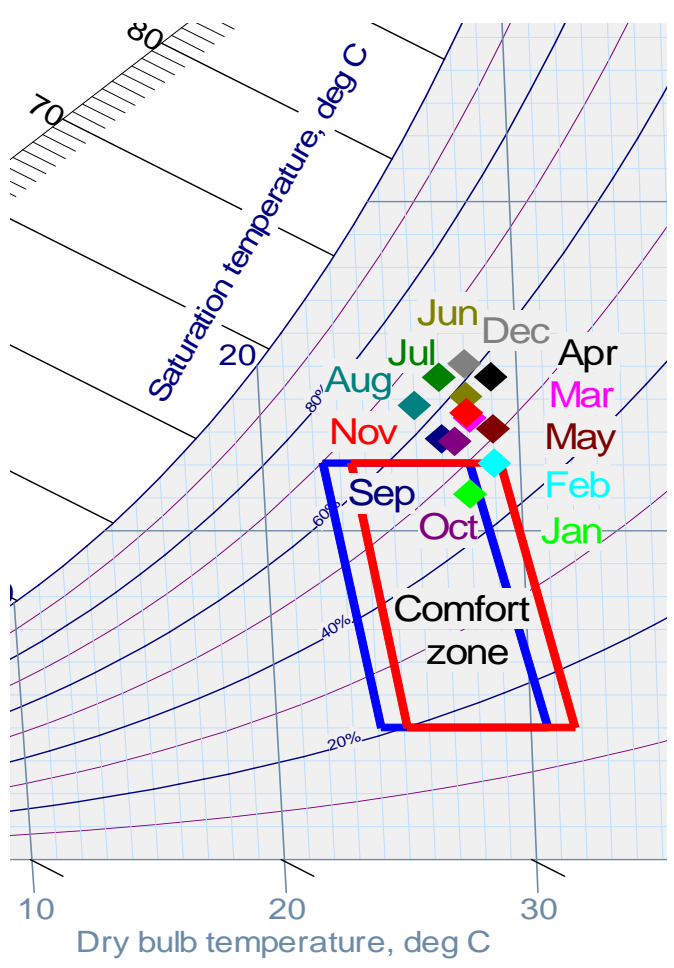

Fig.13: Mean monthly hourly temperature and relative humidity values of offices in ROY (based on measured data from 8 to 17 hrs.

The performance of the ROY building could be due to relatively more glazing on the façade and the effects of direct and reflected solar radiation regarding heat transfer through building envelopes. There are no shading devices on three sides of the monitored spaces and this worsens the situation when inefficient glazing and building systems are employed (Lambeva, 2007).

\section{DCD building}

From Fig. 15, the naturally ventilated building of DCD could be seen as uncomfortable. The mean maximum recorded temperature value $\left(32^{\circ} \mathrm{C}\right)$ was higher than that in all the other buildings. An average temperature value of $30^{\circ}$ $\mathrm{C}$ was computed. However, the mean humidity level was about $60 \%$. This could be due to the 
effect of ventilation, reducing the humidity levels as opposed to the air-conditioned buildings.

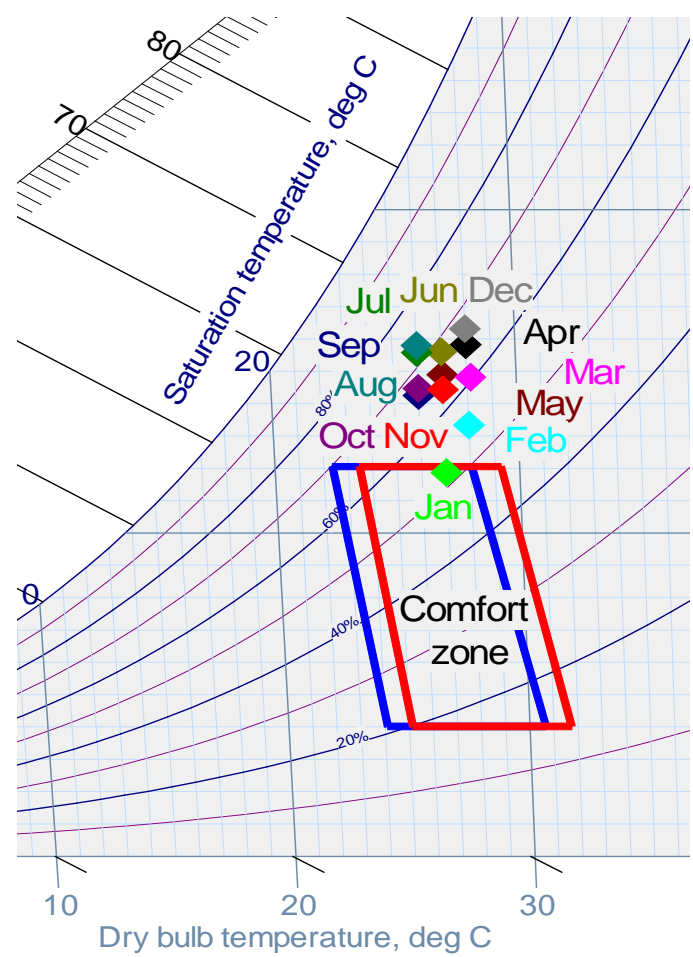

Fig.14: Mean monthly hourly minimum temperature and relative humidity values of offices in ROY (based on measured data from 8 to 17 hrs.)

The mean monthly hourly values of temperature and relative humidity could justify the month of January as comfortable (Fig. 16). The highest mean temperature value was $30^{\circ} \mathrm{C}$ and the lowest $26^{\circ} \mathrm{C}$. The mean relative humidity level was about $70 \%$.

The mean hourly minimum values did not deviate much from Fig. 17 and only the month of January was comfortable.

The poor performance of building DCD could be due to the lack of efficient or even nonexisting building systems, such as fans. The

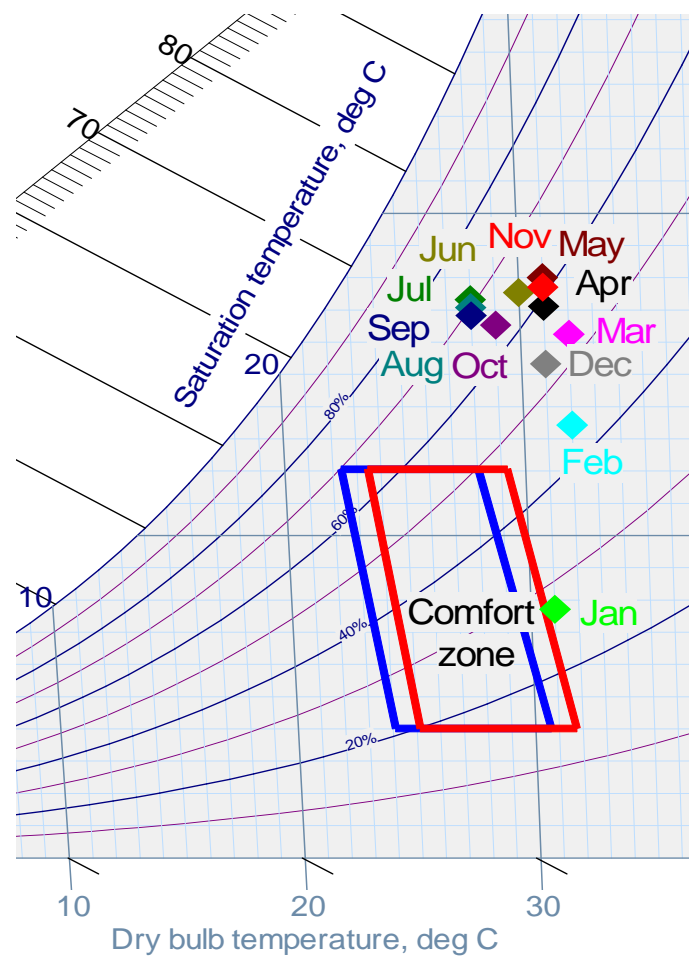

Fig.15: Mean monthly hourly maximum temperature and relative humidity values of offices in DCD (based on measured data from 8 to 17 hrs.)

arrangement of the office spaces did not support sustainable design principles, therefore the positive effects of cross ventilation could not be utilised. Occupants' behaviour in operating the shades is also a factor, as curtain shades remained drawn until close of work, which resulted in a reduction of air speed. In similar studies of office buildings, shading devices were found to be often deployed in the southern sides of buildings and left closed or partly open until the close of the working day (Inoue et al., 1988 and Mahdavi et al., 2007). This behaviour was also observed in the case studied buildings.

The guidelines for sustainable design principles should be followed in a consequent manner, in order to produce a favourable indoor climate, comfort and satisfaction (Lechner, 2001 and Salmon, 1999). The use of fans was found to 
help in the evaporative potential of the skin and should be a priority in all office buildings, especially in naturally ventilated types, since the effect would be thermal sensation reduction of air temperature values of $2-3^{\circ} \mathrm{C}$ (Hyde, 2000).

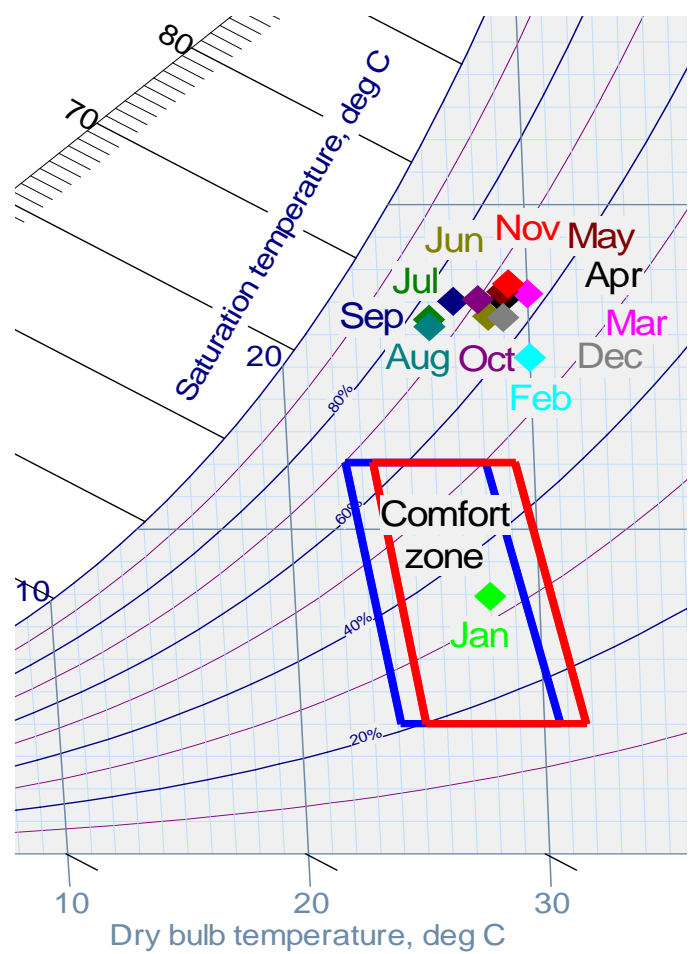

Fig.16: Mean monthly hourly temperature and relative humidity values of offices in DCD (based on measured data from 8 to 17 hrs.)

\section{CONCLUSION}

The existing indoor conditions in the office buildings plotted on the psychrometric charts resulted in almost all the months being represented outside the comfort zone.

The reasons were the high humidity values, even though the temperatures in most of the cases were below $29^{\circ} \mathrm{C}$. The impression gained during the observation period was that occupants were adapted to higher humidity levels and therefore could find maximum humidity

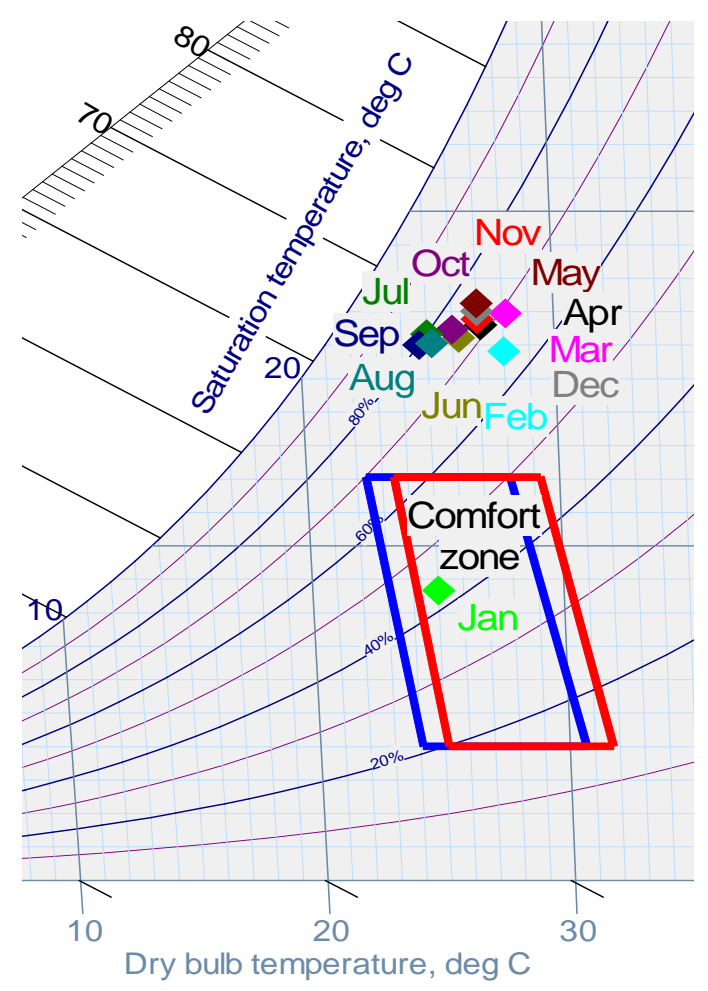

Fig.17: Mean monthly hourly minimum temperature and relative humidity values of offices in DCD (based on measured data from 8 to 17 hrs.)

levels of $80 \%$ comfortable, if temperature values did not exceed $29^{\circ} \mathrm{C}$. However, this temperature is $3^{\circ} \mathrm{C}$ more than the suggestion of Ferstl but tallies with the maximum value under the neutral temperature table. The effect would be the representation of most of the months (temperature and relative humidity plots) inside the comfort zone on the psychrometric chart. This would call for the adjustment of the comfort scale for the climatic context of Kumasi, Ghana.

\section{REFERENCES}

Auliciems, A. (1981). Towards a PsychoPhysiological Model of Thermal Perceptions, International Journal of Biometeorology, 25: 109 - 122. 


\section{Koranteng et al.}

Fanger, P. O. (1973). Thermal Comfort, McGraw Hill Book Company, New York.

Ferstl, K. (2005). Fundamentals of Climatically Appropriate Building and Relevant Design Principles, In: Tropical Architecture by Lauber W., First Edition, Prestel Verlag, Munich, Germany.

Givoni, B. (1976). Man, Climate and Architecture, Second Edition, Van Nostrand Reinhold Company, New York, USA.

Gut, P. and Ackerknecht, D. (1993). Climate Responsive Building, Swiss Centre for Development and Cooperation in Technology and Management, First Edition, SKAT Verlag, Switzerland.

Heerwagen, D. (2004). Passive and Active Environmental Controls: Informing the Schematic Designing of Buildings, First Edition, McGraw Hill, New York.

Herkel, S., Knapp, U. and Pfafferott, J. (2005). A Preliminary Model of User Behaviour Regarding the Manual Control of Windows in Office Buildings, In I. BeausoleilMorrison \& M. Bernier (eds.), Ninth International IBPSA Conference, Building Simulation 2005. Montréal, Canada, 15 18 August, pp. 403 - 410.

Hyde, R. (2000). Climate Responsive Design, First Edition, E \& FN Spon, United Kingdom.

Inoue, T., Kawase, T., Ibamoto, T., Takakusa, S. and Matsuo, Y. (1988). The Development of an Optimal Control System for Window Shading Devices Based on Investigations in Office Buildings, ASHRAE Transaction, 94: 1034 - 1049.

Keneally, V. (2002). An Introduction to Energy Efficiency in Air Conditioned Tropical Buildings, Environmental Design Guide, www.hku.hk/mech/cmhui/sbs/ GEN14.pdf, Pp. 4, Accessed: March 15, 2010.

Koenigsberger, O. H., Ingersoll, T. G., Mayhew A. and Szokolay S.V. (1974). Manual of Tropical Housing and Building: part one, Climatic Design, First Edition, Longman Inc., New York, USA.

Koranteng, C. (2010). An Evaluation of the Thermal Performance of Office Buildings in Ghana, Institute of Building Physics and Human Ecology, Technology University of Vienna.

Lambeva, S. L. (2007). User Interaction with Environmental Control Systems in an Educational Office Building, Technology University of Vienna, Austria.

Lechner, N. (2001). Heating, Cooling, Lighting: Design Methods for Architects, Second Edition, John Wiley \& Sons, Inc., New York, USA.

Love, J. A. (1998). Manual Switching Patterns Observed in Private Offices, Lighting Research \& Technology, 30 (1): 45 - 50.

Mahdavi, A., Mohammadi, A., Kabir, E. and Lambeva, L. (2007). User Control Actions in Buildings: Patterns and Impact, Well Being Indoors. Clima 2007, 10 - 14 June, Helsinki, Finland, Seppänen O, Säteri J, (Ed.), ISBN: 978-952-99898-2-9. PaperNo. C03.

Mohammadi, A. (2007). Modelling Occupants' Control Actions and their Energy Implications in an Office Building, Technology University of Vienna, Austria.

Mokamelkhah, E. K. (2007). Lighting, Shading and Ventilation Controls: A Study of User Behaviour in Office Buildings, Technology University of Vienna, Austria. 
Nicol, F. J. (2001). Characterising Occupant Behaviour in Buildings: Towards a Stochastic Model of Occupant Use of Windows, Lights, Blinds, Heaters and Fans, Seventh International IBPSA Conference, Rio de Janeiro, Brazil, August 13-15, pp. 1073 - 1078.

Nicol, F. and Roaf, S. (2005). Post-Occupancy Evaluation and Field Studies of Thermal Comfort, Building Research and Information, 33(4): 338 - 349, July/August 2005.

Olgyay, V. (1963). Design with Climate: Bioclimatic Approach to Architectural Regionalism, First Edition, Princeton University Press, New Jersey, USA.

Pigg, S., Eilers, M., and Reed J. (1996). Behavioural Aspects of Lighting and Occupancy Sensors in Private Office: A Case Study of a University Office Building, In ACEEE, (American Council for an Energy Efficient Economy) 1996 ACEEE Summer Study on Energy Efficiency in Buildings: Profiting from Energy Efficiency. Pacific Grove, CA, 25 - 31 August. ACEEE: Washington D.C., 8.161 - 8.171.
Rijal, H. B., Tuohy, P., Humphreys, M. A., Nicol, J. F., Samuel, A., Raja, I. A. and Clarke, J. (2008). Development of Adative Algorithms for the Operation of Windows, Fans and Doors to Predict Thermal Comfort and Energy Use in Pakistani Buildings, ASHRAE Transactions, Atlanta, USA.

Salmon, C. (1999). Architectural Design for Tropical Regions, First Edition, John Wiley \& Sons, Inc., New York, USA.

Stein, B. and Reynolds, J. S. (2000). Mechanical and Electrical Equipment for Buildings, Ninth Edition, John Wiley \& Sons, Inc., New York, USA.

Sutter, Y., Dumortier D. and Fontoynont, M. (2006). The Use of Shading Systems in VDU Task Offices: A Pilot Study, Energy and Buildings, 38(7): 780 - 789.

Szokolay, S. (2004). Introduction to Architectural Science: The Basis of Sustainable Design, First Edition, Architectural Press, Oxford, UK. 